\title{
ANALISIS KERENTANAN SITUS HERITAGE TERHADAP ANCAMAN LETUSAN GUNUNG API SINABUNG
}

\author{
Nazli Ismail1,2, M Yanis', Lucki Armanda ${ }^{1,4}$, M Syukri Surbakti2 \\ 1Program Studi Magister Ilmu Kebencanaan, Universitas Syiah Kuala \\ 2Program Studi Fisika, Universitas Syiah Kuala \\ 3 Program Studi Teknik Geofisika, Universitas Syiah Kuala \\ Jl. Teuku Nyak Arief, Darussalam, Banda Aceh, 23111, Indonesia \\ ${ }^{4}$ Balai Pelestarian Cagar Budaya Aceh \\ Jl. Teuku Umar no.1 Banda Aceh, 23111, Indonesia \\ e-mail: nazli.ismail@unsyiah.ac.id
}

\begin{abstract}
Abstrak
Sumber daya arkeologi sebagai wujud pemikiran dan tingkah laku kehidupan manusia pada masa lampau sangat penting bagi pengembangan sejarah sehingga perlu dilestarikan. Bencana alam merupakan salah satu actor yang dapat menyebabkan kerusakan dan kepunahan terhadap sumber daya arkeologi. Pada penelitian ini dilakukan pemetaan terhadap sumberdaya arkeologi di Kabupaten Karo yang dioverlay terhadap peta risiko bencana Gunung Api Sinabung. Proses ini dilakukan untuk analisis tingkat kerentanan sumber daya arkeologi terhadap dampak bencana gunung api. Hasil observasi menunjukkan sumber daya arkeologi tersebut masuk dalam tingkat kerawanan sedang atau relatif membahayakan. Dampak dari abu vulkanik yang diakibatkan oleh letusan gunung api Sinabung masih berpotensi memberikan kerusakan jangka panjang. Oleh karena itu pengelolaan cagar budaya yang berdamapak pada pelestarian harus membuka ruang keterlibatan setiap pemangku kepentingan termasuk masyarakat.
\end{abstract}

Kata kunci: bahaya Gunung Api, Konservasi Cagar Budaya, Mitigasi Bencana, Peta Bahaya.

\begin{abstract}
Archaeological resources as a form of thought and behavior of human life are considerably important in developing of history so that it needs to be preserved. One of the factors that cause damage and extinction of archeological resources is natural disasters, in this study we have mapped archeological resources in Karo District and overlaid them on the Sinabung volcano hazards map. This process was carried out in order to analyze the level of vulnerability of archeological resources to the impact of volcanic disasters. The results show that vulnerability of the archeological resources is categorized at low to moderate levels. However, the influence of volcanic ash produced by the Sinabung volcanic eruption is expected as the most potential hazard to provide long-term damage. Therefore, efforts for conservation are urgently needed.
\end{abstract}

Keywords: Volcano hazards, Cultural Reserve Conservation, Disaster Mitigation, Hazard Maps.

\section{PENDAHULUAN}

Indonesia merupakan negara yang terletak pada pertumbukan tiga lempeng tektonik yaitu Eurasia, Indo-Australia, dan lempeng Pasifik. Hal ini menjadikan Indonesia sebagai wilayah yang mempunyai cadangan mineral berlimpah, namun pada sisi lain mempunyai banyak 
gunung api aktif yang dapat berpotensi menimbulkan erupsi dan menyebabkan bencana gempa bumi (Sieh and Natawidjaja, 2000). Gunung Sinabung merupakan salah satu dari banyak gunung api yang terletak di Kab. Karo, Provinsi Sumatera Utara. Aktivitas seismik mencatat bahwa semenjak tahun 1600 hingga tahun 2000-an gunung ini tidak pernah mengalami erupsi, tetapi mendadak aktif kembali tahun 2010 (BNPB, 2014).

$$
\text { Gunung api Sinabung }
$$
menghembuskan material abu vulkanik mencapai ketinggian 7 sampai 8 kilometer. Abu tersebut telah menyebar jauh hingga mencapai Kota Medan dengan jarak $80 \mathrm{~km}$ dari gunung api. Untuk mengurangi dampak risiko bencana, berbagai upaya telah dilakukan oleh Badan Nasional Penanggulangan Bencana (BNPB, 2012), namun semua usaha tersebut hanya difokuskan pada upaya penyelamatan manusia, padahal berdasarkan kerangka Hyogo Sendai penanggulangan bencana tidak hanya fokus pada urusan penyelamatan manusia saja tetapi juga ada hal yang tidak kalah penting juga yaitu situs cagar budaya (Auker, et.al, 2013; Troll, et.al, 2015).
Merujuk kepada Scovil, et al. (1977) bahwa sumber daya arkeologi merupakan sisa budaya yang ditinggalkan oleh manusia pada masa lampau dibentangan alam yang dapat bermanfaat untuk menggambarkan, menjelaskan, serta memahami tingkah laku dan interaksi masa lampau sebagai bagian yang tidak dapat dipisahkan dari perubahan sistem budaya dan alamnya. Selain itu fungsi cagar budaya juga menjadi identitas sebuah bangsa (Burley, 1998; Capasso, 2000).

Aktivitas letusan Gunung Api Sinabung tidak hanya mengancam aktivitas kehidupan manusia yang tinggal di sekitarnya. Lebih dari itu, Tanah Karo juga menyimpan kekayaan budaya yang sangat berpotensi menjadi cagar budaya. Namun sumber daya arkeologi tersebut dinilai rentan terhadap dampak erupsi gunung api Sinabung yang saat ini masih aktif. Bahaya letusan gunung api dapat berpengaruh terhadap kelestarian situs arkeologi. Wilson, et al., (2014) merincikan bahwa terdapat 9 jenis bahaya gunung api yang perlu diwaspadai, secara lengkap ditunjukan oleh Tabel 1.

Tabel 1. Bahaya-bahaya Letusan Gunung Api

\begin{tabular}{|c|c|c|}
\hline No & Bahaya & Keterangan \\
\hline 1 & Leleran lava & $\begin{array}{l}\text { Cairan lava yang pekat dan panas dapat merusak segala infrastruktur } \\
\text { yang dilaluinya. }\end{array}$ \\
\hline 2 & Aliran piroklastik & $\begin{array}{l}\text { Dapat terjadi akibat runtuhan tiang asap erupsi plinian, letusan } \\
\text { langsung ke satu arah, guguran kubah lava atau lidah lava dan aliran } \\
\text { pada permukaan tanah (surge). }\end{array}$ \\
\hline 3 & Jatuhan piroklastik & $\begin{array}{l}\text { Terjadi dari letusan yang membentuk tiang asap cukup tinggi, pada saat } \\
\text { energinya habis, abu akan menyebar sesuai arah angin kemudian jatuh } \\
\text { lagi ke muka bumi. }\end{array}$ \\
\hline 5 & Lahar letusan & Terjadi pada gunung api yang mempunyai danau kawah. \\
\hline 6 & Gas vulkanik beracun & $\begin{array}{l}\text { Gas beracun umumnya muncul pada gunung api aktif berupa } \mathrm{CO}, \mathrm{CO} 2 \\
\mathrm{HCN}, \mathrm{H} 2 \mathrm{~S}, \mathrm{SO} 2 \mathrm{dll}\end{array}$ \\
\hline 7 & Lahar hujan & $\begin{array}{l}\text { terjadi apabila endapan material lepas hasil erupsi gunungapi yang } \\
\text { diendapkan pada puncak dan lereng, terangkut oleh hujan atau air } \\
\text { permukaan. }\end{array}$ \\
\hline 8 & Banjir bandang & $\begin{array}{l}\text { terjadi akibat longsoran material vulkanik lama pada lereng gunung api } \\
\text { karena jenuh air atau curah hujan cukup tinggi }\end{array}$ \\
\hline 9 & Longsoran vulkanik & $\begin{array}{l}\text { terjadi akibat letusan gunung api, eksplosi uap air, alterasi batuan pada } \\
\text { tubuh gunung api sehingga menjadi rapuh, atau terkena gempa bumi } \\
\text { berintensitas kuat. }\end{array}$ \\
\hline
\end{tabular}

Sumber: Wilson, 2014

Ke-sembilan bahaya tersebut sangat berpotensi terjadi pada Gunung Sinabung yang merupakan tipe strato dengan bentuk kerucut yang mendekati sempurna. 
Gunung api Sinabung terbentuk pada daerah tepian barat laut sesar cekungan Toba Tua.

Dengan demikian sebagai upaya mitigasi terhadap tinggalan sumber daya arkeologi, maka pada penelitian ini kami melakukan pemetaan terhadap situs cagar budaya, melakukan analisa kerentanan setiap situs terhadap dampak aktivitas vulkanik serta menerapkan metode penyelamatan yang cocok untuk setiap situs tersebut.

\section{METODE PENELITIAN}

Mitigasi sumber daya arkeologi terhadap letusan gunung api Sinabung diproses berdasarkan penggunaan teknik sistem informasi geografis, baik untuk pemetaan sumber daya arkeologi, analisis potensi bencana gunung api dan risiko sumber daya arkeologi.

Analisis pemetaan dilakukan secara overlay dalam bentuk vector dan grid. Teknik pemetaan sumber daya arkeologi yang akan dilakukan pada penelitian antara lain adalah (1) Penggabungan data vector lokasi sumber daya arkeologi terhadap peta situasional Kabupaten Karo, (2) definisi interval warna terhadap daerah zona evakuasi bencana letusan Gunung Api Sinabung, dan (3) Pembuatan peta risiko sumber daya arkeologi berdasarkan overlay situasional gunung api dan lokasi sumber daya arkeologi. Secara lebih ringkas tahapan metode yang dilakukan pada penelitian ini ditunjukkan oleh Gambar 1.

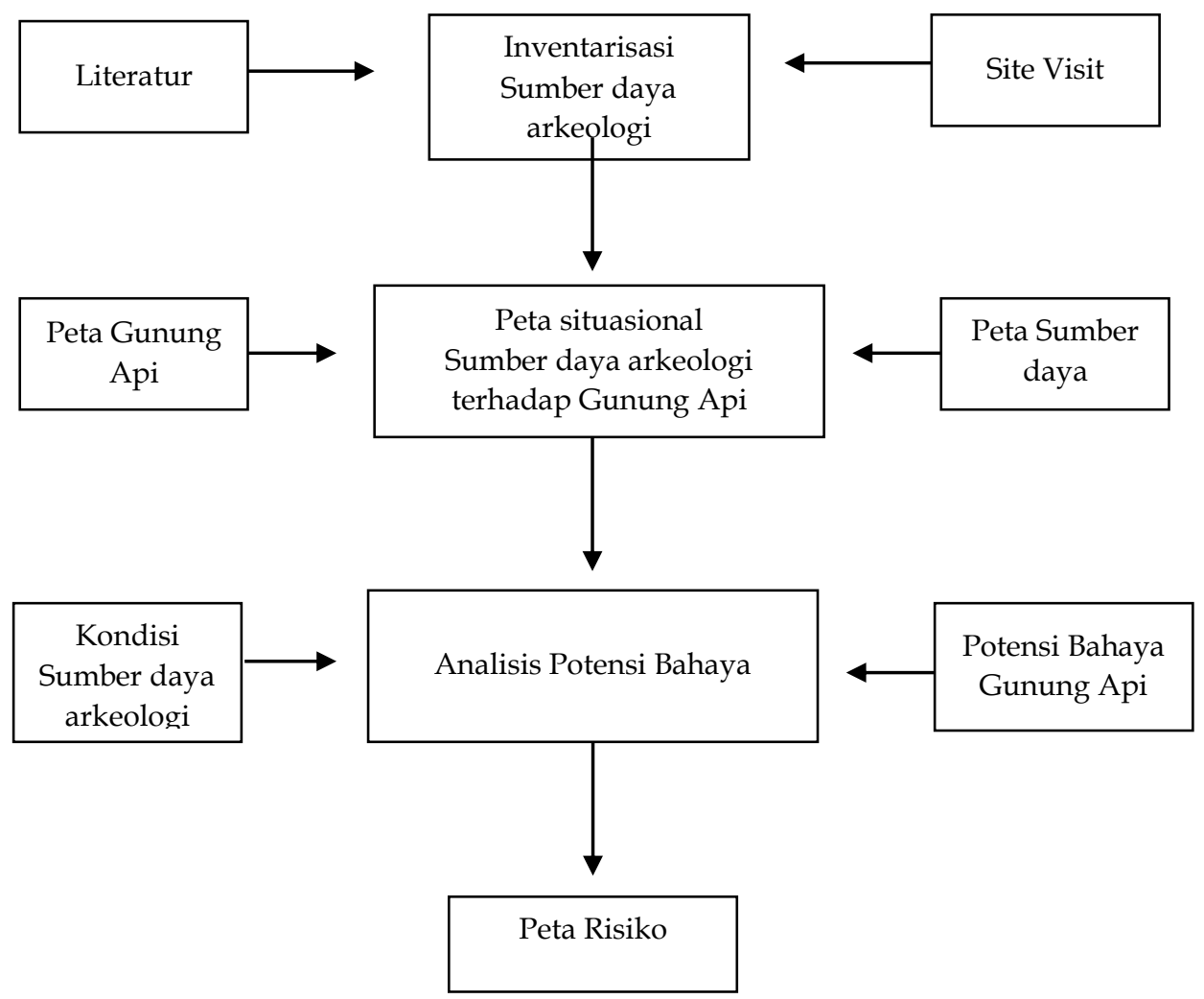

Gambar 1. Bagan alir penelitian. Peta risiko situs arkeologi dapat diperoleh melalui integrasi peta situasional situs terhadap analasis potensi bahaya letusan Gunung Api.

Untuk dapat menggambarkan peta situasional dari situs arkeologi yang berada pada area relatif dekat dengan Gunung Api Sinabung, maka dibutuhkan beberapa informasi dari keadaan situs tersebut seperti kondisi bangunan, jumlah bangunan, orientasi situs beserta umurnya, semua informasi ini diperoleh melalui 
observasi lapangan. Selain kondisi situs, untuk menggambarkan kondisi situasional dari gunung api maka dibutuhkan juga beberapa informasi antara lain lingkaran jarak letusan gunung api dengan berbagai tempat, jalur transportasi dan ketinggian gunung api, semua informasi ini diperoleh dari studi literature yang bersumber dari BNPB dan USGS. Secara lengkap Informasi dan sumber yang dibutuhkan untuk peta analisis risiko situs arkeologi ditunjukan oleh Tabel 2.

Tabel 2. Informasi dan Sumber Penggunaan Data Untuk Analisis risiko Bencana Letusan Gunung Api Sinabung.

\begin{tabular}{|c|c|c|c|c|}
\hline No & Nama Peta & Informasi yang dibutuhkan & Sumber Informasi & Keterangan \\
\hline 1 & $\begin{array}{l}\text { Peta Situasional } \\
\text { Sumber daya } \\
\text { arkeologi }\end{array}$ & $\begin{array}{l}\text { Lokasi dan ID } \\
\text { Foto Situs Sumber daya arkeologi } \\
\text { Umur bangunan } \\
\text { Ketinggian bangunan } \\
\text { Struktur dinding bangunan } \\
\text { Panjang dan tinggi dinding } \\
\text { Struktur atap } \\
\text { Orientasi bangunan } \\
\text { Jumlah, dan ukuran } \\
\text { Jenis bagian yang terbuka pada } \\
\text { bangunan }\end{array}$ & $\begin{array}{l}\text { Observasi lapangan atau } \\
\text { site visit }\end{array}$ & $\begin{array}{l}\text { Menggunakan GPS } \\
\text { Menggunkan Canon EOS } \\
\text { 60D } \\
\text { Analisis langsung di lokasi }\end{array}$ \\
\hline \multirow[t]{3}{*}{2} & $\begin{array}{l}\text { Peta Situasional } \\
\text { Gunung Api }\end{array}$ & $\begin{array}{l}\text { Lingkaran jarak letusan gunung } \\
\text { api dengan berbagai tempat } \\
\text { Batas administrasi desa } \\
\text { Jaringan jalan } \\
\text { Transportasi } \\
\text { Informasi hidrologi }\end{array}$ & BNPB, 2010 & Kajian Literatur \\
\hline & & Kawasan rawan bencana & BNPB, 2014 & \\
\hline & & Ketinggian gunung api & USGS Earth Explorer & \\
\hline
\end{tabular}

\section{HASIL DAN PEMBAHASAN}

Kabupaten Karo, Sumatera Utara merupakan daerah yang banyak terdapat sumber daya arkeologi yang perlu dilestarikan, dampak bencana yang bisa terjadi kapanpun menyebabkan rusaknya sumber daya arkeologi di kawasan tersebut. Oleh sebab itu letak dan strategis keadaan arkeologi atau bangunan peninggalan sejarah di Tanah Karo. Secara lengkap distribusi situs-situs arkeologis di Kabupaten Karo ditunjukkan oleh Gambar. 2 yang telah di-overlay dengan informasi jalur transportasi menuju situs.

Berdasarkan peta distribusi benda arkeologis, ada 19 situs peninggalan sejarah yang merupakan sumber daya arkeologi yang dirasa perlu diselamatkan dari dampak ancaman gunung api yang terdapat di Kab. Karo Sumatera Utara diantaranya: Rumah Adat Lingga yang berada di Kabupaten Karo berbentuk seperti rumah adat Suku Batak pada umumnya, seperti rumah adat yang ada di wilayah Toba, Mandailing, Simalungun, Dairi dan Pakpak. Rumah yang berbentuk panggung ini keseluruhan material bangunannya terbuat dari bahan kayu dengan atap rumah berbahan ijuk. Di sekitar bangunan rumah adat ini dikelilingi kebun, jalan dan rumah penduduk yang bangunannya terbuat dari kayu.

Makam Tengku Lau Bahun Lingga/Nini Teungku, Batu nisan di situs makam terbuat dari batu andesit. Terdapat bangunan kayu yang menjadi cungkup makam. Letak makam tokoh ini saat sekarang berada di perbatasan antara Desa Lingga dengan Desa Surbakti.

Makam Sibayak Lingga, bangunan makam pada situs ini berbahan beton dengan dilapisi keramik. Menurut sumber setempat dan catatan di masing-masing tugu, di komplek makam ini dimakamkan 
raja-raja Lingga yang memerintah sejak awal abad ke-XX, yaitu tahun 1922 dari raja pertama sampai ke raja ketiga memerintah hingga tahun 1947 Masehi.

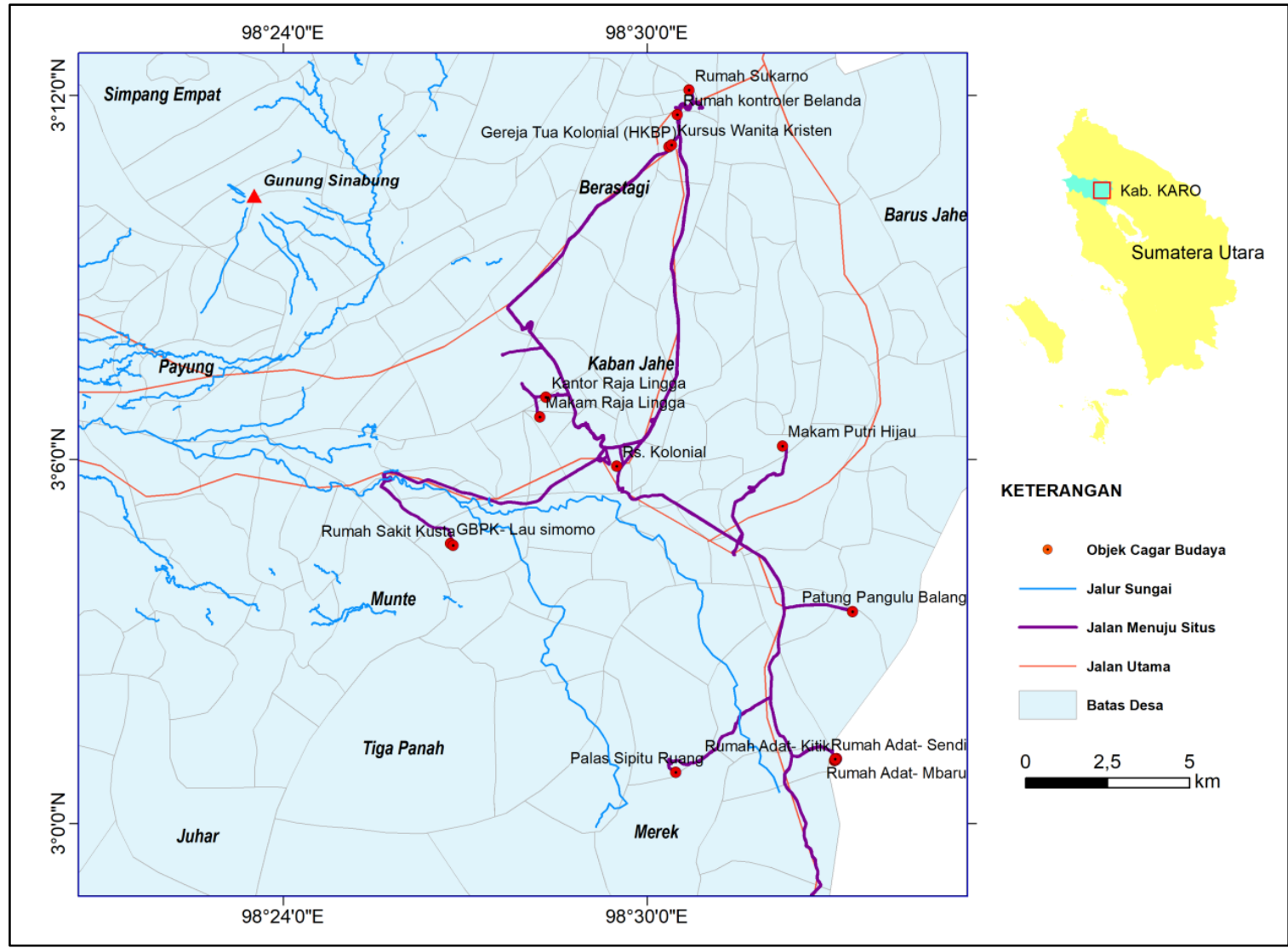

Gambar 2. Peta Lokasi Bangunan dan Situs yang Mempunyai Potensi Sumber Daya Arkeologi di Kabupaten Karo

Aktivitas gunung api dimulai dari kegiatan magma yang berasal dari dalam bumi. Magma dapat terdorong ke permukaan karena sifatnya yang pekat dan mendapatkan tekanan sehingga terjadi erupsi. Erupsi non-eksplosif (effusive) terjadi jika kepekatan magma rendah dan kandungan gas kurang di dalam magma. Erupsi non-eksplosif sering berbentuk aliran lava. Letusan Gunung Api Sinabung termasuk dalam tipe semi-vulkanian. Ciri letusan semi-vulkanian di antaranya adalah adanya luncuran awan panas ke arah kaki gunung dan erupsi debu vulkanik pekat ke udara. Aliran erupsi umumnya menuju arah selatan dan tenggara karena titik tumbuh kubah lava berada pada kawah yang menuju ke sektor tersebut. Oleh karena itu, Pusat Vulkanologi dan Mitigasi Bencana Geologi (PVMBG) menetapkan kawasan tersebut menjadi area terlarang bagi aktivitas manusia yang meliputi sektor selatan hingga radius mencapai 7 kilometer dari puncak, pada sektor tenggara hingga radius mendatar 5 kilometer sedangkan sektor lain yang tersisa hingga mencapai radius mendatar 3 kilometer.

Aktivitas letusan Gunung Api Sinabung tidak hanya mengancam aktivitas kehidupan manusia yang tinggal di sekitarnya. Lebih dari itu, Tanah Karo juga menyimpan kekayaan budaya yang bernilai tinggi seperti tinggalan sumber daya arkeologi yang berpotensi menjadi cagar budaya. Kegiatan observasi terhadap keletakan dan kondisi ke 19 sumber daya arkeologi yang ada di Kab. Karo perlu dilakukan sebagai upaya mitigasi bencana letusan gunung api. Upaya - upaya observasi tersebut salah satunya di lokasi Rumah Adat Karo. 


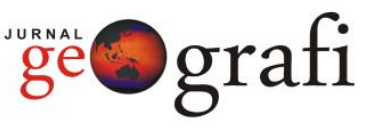

Rumah adat Karo terletak di Desa Dokan, Kecamatan Merek. Lokasi ini merupakan komplek perumahan adat Karo yang terdiri dari 5 unit perumahan, yaitu Mbaru, Sendi, Tengah, Mbelin dan Ketek. Akses ke lokasi ini tergolong mudah yaitu dapat dicapai dengan jarak $2 \mathrm{~km}$ dari jalan besar Kabanjahe-Merek.

Secara keseluruhan kondisi bangunan adat Karo relatif bagus dimana dinding bangunan, lantai dan juga cat masih terlihat kokoh, namun demikian beberapa atap rumah adat seperti Tengah dan Mbaro

terdapat tumbuhan lumut yang tebal, diskripsi rumah adat secara lengkap ditunjukan oleh Gambar 3. Jika dipandang dari aspek mitigasi rumah adat Karo tergolong kepada bangunan tanggap bencana. Bentuknya berupa rumah panggung sehingga relatif aman terhadap banjir. Perekat yang digunakan untuk mengikat dinding rumah terbuat dari pasak kayu, kondisi ini juga dapat menyebabkan rumah adat Karo ramah terhadap zona gempa.
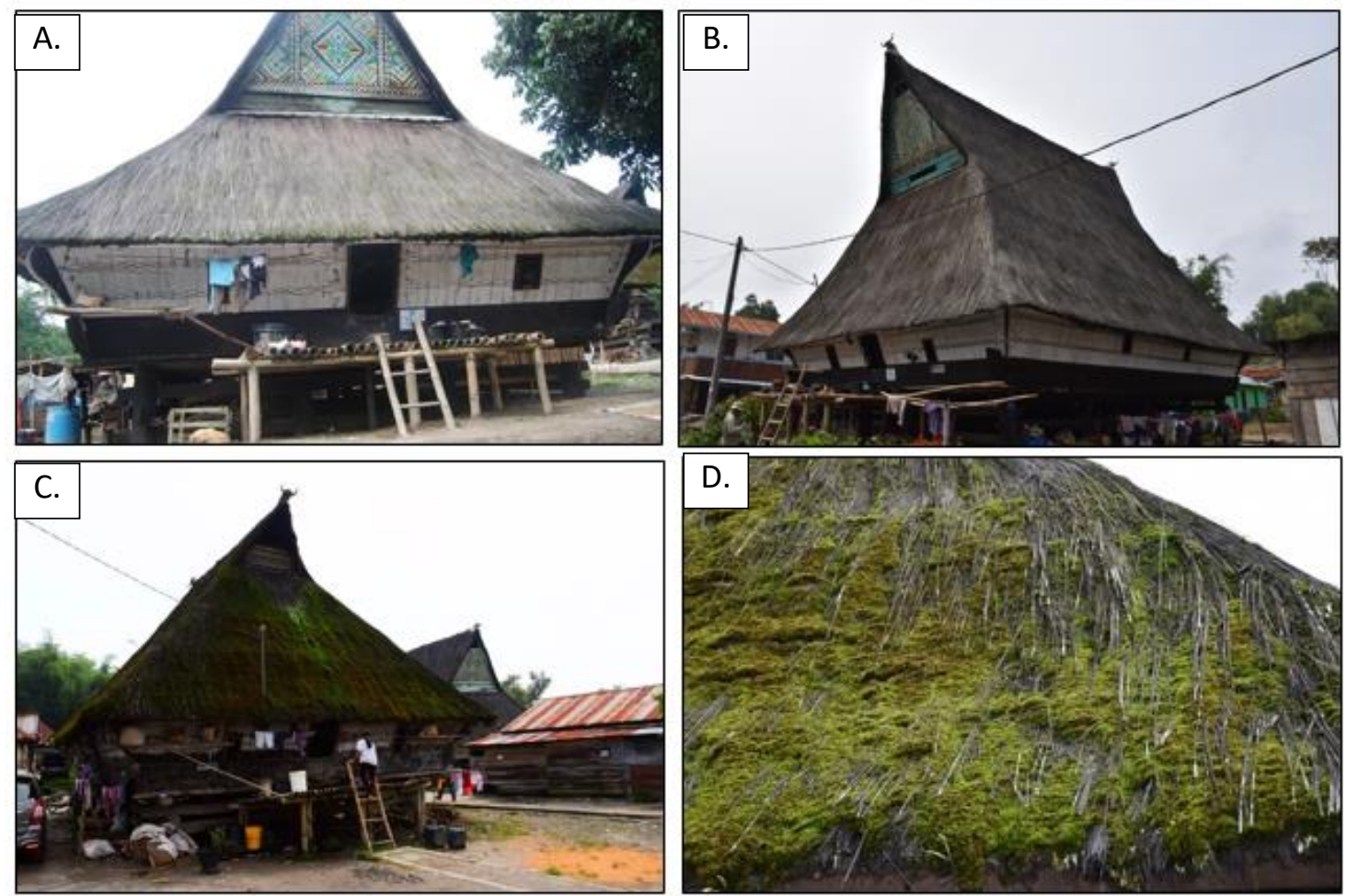

Gambar 3. Kondisi fisik bangunan rumah adat Karo di desa Dokan. (a). Rumah adat Mbaru.

(b). Rumah adat Ketek. (c). Rumah adat Tengah dengan atap yang telah berjamur. (d).

Kondisi digredasi biologis disebabkan oleh tumbuhan diatas atap beberapa rumah adat Karo yaitu Tengah dan Sendi.

Desa Dokan terletak pada ketinggian 1290 meter dari permukaan laut. Berdasarkan peta citra satelit secara umum rumah adat tersebut dibatasi oleh pemukiman masyarakat, namun sebelah Timur dari rumah adat terdapat zona perbukitan yang dihimpit oleh aliran sungai dengan jarak 500 meter, sehingga kondisi yang demikian dapat mencegah bangunan tersebut dari ancaman lahar dingin erupsi gunung Sinabung. Rumah adat Karo terletak di sebelah timur dari gunug Sinabung dengan jarak $19 \mathrm{~km}$, sehingga risiko paling mungkin terjadi adalah guguran vulkanik yang dapat merusak bangunan dengan timbunan volume yang besar. Disisi lain atap rumah yang berbentuk limas dapat menjadi salah satu upaya mitigasi terhadap tumpukan material debu vulkanik dari gunung Sinabung. 
Berdasarkan hasil pemetaan disribusi sebaran Sumber Daya Arkeologi, dan identifikasi kerentanannya terhadap ancaman letusan gunung api Sinabung menghasilkan peta risiko bencana. Data dari BNPB pada tahun 2014 menunjukan potensi kerawanan letusan gunung api Sinabung di Kabupaten Karo yang terbagi menjadi 3 zona rawan bencana.

\section{Kawasan Rawan Bencana III}

Kawasan rawan bencana III merupakan wilayah yang sangat berpotensi terpapar awan panas, aliran lava, guguran larva, gas vulkanik beracun dan aliran lahar. Pada peta diskripsikan dengan warna merah. Batas kawasan sangat berpotensi tertimpa lontaran material batu (pijar) berdiameter lebih dari $6 \mathrm{~cm}$ dan hujan abu lebat ditunjukkan dengan garis yang diarsir berwarna merah.

\section{Kawasan Rawan Bencana II}

Kawasan rawan bencana II berpotensi terlanda awan panas aliran lava, guguran lava, gas vulkanik beracun dan aliran lahar. Batas kawasan sangat berpotensi tertimpa lontaran batu (pijar) berdiameter 2-6 cm dan hujan abu (lebat).

\section{Kawasan Rawan Bencana I}

Kawasan rawan bencana I berpotensi terlanda aliran lahar. Batas kawasan sangat berpotensi tertimpa lontaran material batu (pijar) berdiameter kurang dari $2 \mathrm{~cm}$.

Secara lengkap gambaran kawasan rawan bencana gunung api Sinabung yang telah di overlay dengan lokasi potensi cagar budaya ditunjukkan oleh Gambar 4.

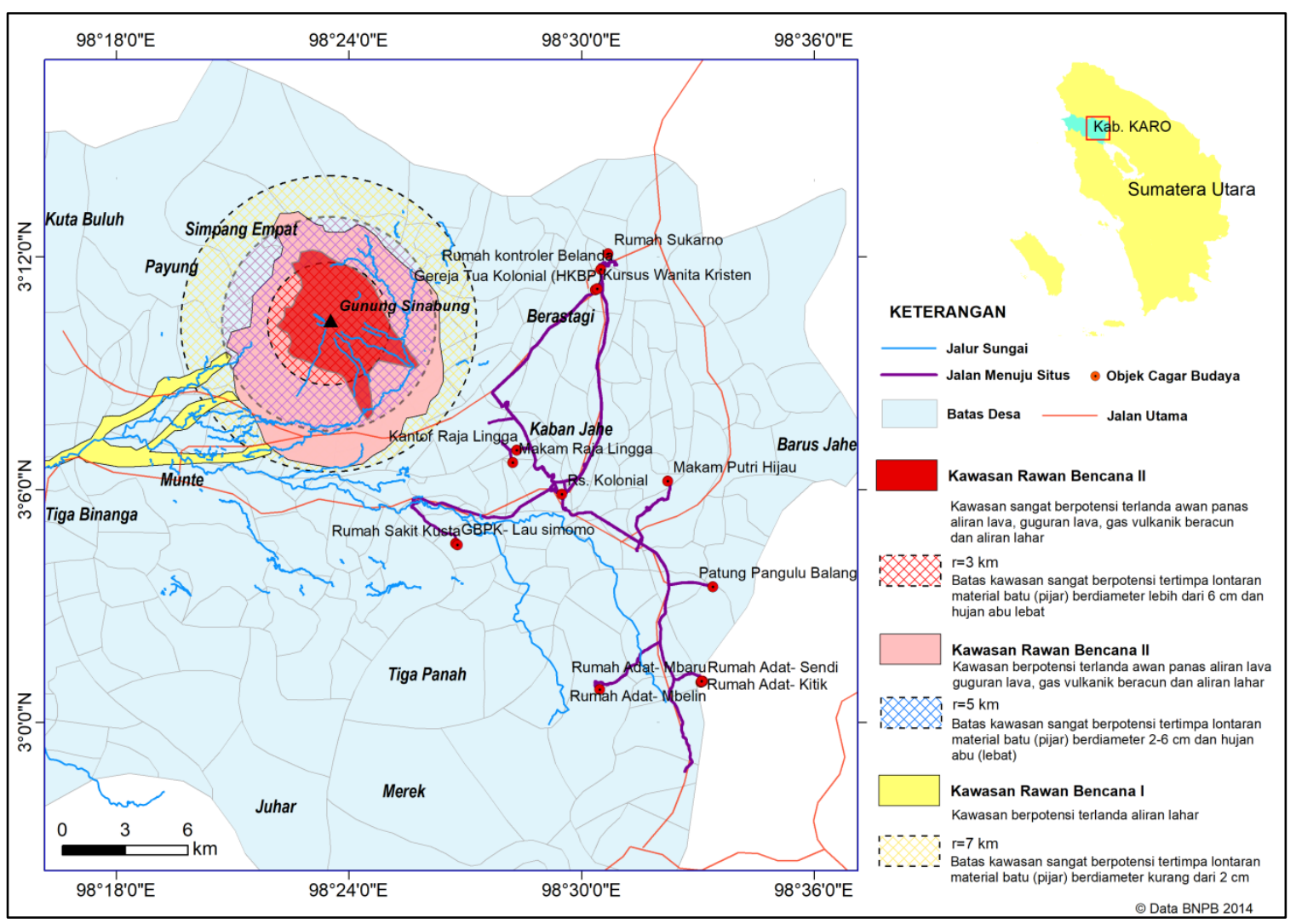

Gambar 4. Peta kawasan rawan bencana Gunung Api Sinabung yang di-overlay dengan distribusi sebaran sumber daya arkeologi di tanah Karo.

Kawasan yang banyak terdapat tinggalan sumber daya arkeologi berada di luar area bahaya gunung api Sinabung, namun demikian, dampak dari aktivitas gunung api Sinabung juga terasa hingga lokasi yang terdapat sumber daya 
arkeologi. Salah contoh adalah aktivitas Gunung api Sinabung pada tahun 2010 yang mengakibatkan hujan abu di sekitar gunung api Sinabung termasuk menjangkau kawasan sekitar Kabupaten Karo. Hujan abu yang terjadi menyebabkan sumber daya arkeologi yang ada tertutup oleh abu vulkanik gunung api Sinabung.
Berdasarkan zonasi wilayah peta resiko bencana letusan gunung api Sinabung yang dapat berkorelasi dengan distribusi sebaran sumber daya alam serta aspek kerentanannya, maka dapat dikelompokan kedalam 3 (tiga) kriteria pembobotan kerentanan sumber daya alam yang secara lengkap ditunjukkan oleh Tabel 3.

Tabel 3. Kriteria pembobotan Kerentanan Gunung Sinabung Alam terhadap Sumber Daya Arkeologi.

\begin{tabular}{|c|c|c|}
\hline No & Kategori & Sumber Daya Arkeologi \\
\hline 1. & Kriteria sangat bahaya & $\begin{array}{l}\text { Untuk saat ini dari data keletakan sumber daya arkeologi yang dikumpulkan di } \\
\text { lapangan, tidak terdapat sumber daya arkeologi yang termasuk ke dalam } \\
\text { kriteria sangat bahaya. }\end{array}$ \\
\hline 2. & Kriteria bahaya & $\begin{array}{l}\text { Adapun sumber daya arkeologi yang termasuk ke dalam kriteria bahaya, antara } \\
\text { lain: Rumah Soekarno, Gereja HKBP Kolonial, Gedung Kursus Wanita, Rumah } \\
\text { Kontroler Belanda, Makam Tengku Law Bahun, Makam Raja Lingga, Kantor } \\
\text { Administrasi Raja Urung, Rumah Sakit Kusta masa kolonial dan Komplek } \\
\text { Rumah penderita kusta. }\end{array}$ \\
\hline 3. & Kriteria kurang bahaya & $\begin{array}{l}\text { Adapun sumber daya arkeologi yang termasuk kriteria kurang bahaya ialah: } \\
\text { Sapo Ganjang, Rumah Adat Dokan, Rumah Adat Mbaru, Rumah Adat Tengah, } \\
\text { Rumah Adat Sendi, Rumah Adat kitik, Palas Sipitu Ruang, Patung Pangulu } \\
\text { Balang dan Makam Putri Hijau. }\end{array}$ \\
\hline
\end{tabular}

Sumber: Analisis Data, 2018

Oleh karena kebanyakan sumber daya arkeologi yang ada di Kab. Karo merupakan bangunan berbahan kayu dan situs yang rentan mengalami kerusakan terutama yang disebabkan bencana gunung api, maka Sumber daya arkeologi tersebut harus dijaga kelestariannya dari berbagai macam gangguan termasuk perlindungan terhadap ancaman bencana gunung api. Meskipun sumber daya arkeologi ini belum ditetapkan sebagai cagar budaya, namun dari hasil penilaian nilai penting bangunan dan situs yang ada memenuhi kriteria sebagai cagar budaya.

Berdasarkan lokasi sumber daya arkeologi yang terdapat di Kabupaten Karo dan korelasinya terhadap ancaman bencana gunung api Sinabung, maka upaya pencegahan dan mitigasi yang bertujuan untuk mengurangi resiko yang ditimbulkan oleh letusan gunung api Sinabung, antara lain:

1. Melakukan pendataan sumber daya arkeologi yang ada di Kabupaten Karo secara lengkap dan menyeluruh. Pada tahap awal ini sumber daya arkeologi yang ada di Kabupaten Karo didata secara menyeluruh berdasarkan lokasinya.

2. Melakukan pemetaan sumber daya arkeologi dan permasalahan yang ditimbulkan akibat letusan gunung api Sinabung. Hasil dari pemetaan pada daerah rawan bencana ini sangat berguna untuk mengetahui kondisi lingkungan sumber daya arkeologi yang masuk dalam daerah rawan bencana, sehingga dapat dilakukan persiapan dan perkuatan struktural bagi sumber daya arkeologi yang berpotensi memiliki nilai penting bagi kebudayaan.

3. Menentukan prioritas sumber daya arkeologi di Kabupaten Karo. Dilakukannya penentuan prioritas penanganan pada sumber daya arkeologi sehingga dapat diketahui jika terjadi kerusakan akibat bencana gunung api Sinabung.

4. Sosialisasi dan penyebarluasan informasi tentang tata cara penyelamatan sumber 
daya arkeologi yang terdapat di Kabupaten Karo, sehingga masyarakat dapat mengantisipasi jika timbul bencana alam yang akhirnya dapat memperkecil korban dan kerusakan yang timbul termasuk kerusakan pada sumber daya arkeologi.

5. Meningkatkan kerjasama dengan kelompok sosial masyarakat di wilayah Kabupaten Karo yang terdampak langsung oleh letusan gunung api Sinabung. Dengan cara Melakukan pelatihan dan simulasi siaga bencana cagar budaya setidaknya dua kali dalam setahun.

6. Membuat dan menempatkan tandatanda peringatan, bahaya, larangan memasuki daerah rawan bencana, informasi jalur evakuasi dan sebagainya.

7. Membuat bangunan/struktur pengaman di sekitar cagar budaya, misalnya cungkup untuk mengamankan bangunan cagar budaya dari abu vulkanik hasil letusan gunung api Sinabung.

8. Mengevakuasi sumber daya arkeologi sesuai prioritas dan yang rentan terhadap pengaruh letusan gunung api Sinabung. Evakuasi dilakukan pada sumber daya arkeologi bergerak seperti patung dan koleksi yang terdapat di Museum Karo Lingga.

9. Melokalisir dan menutup lokasi cagar budaya serta mengamankannya. Hal ini dilakukan agar mengamankan bangunan-bangunan yang terkena dampak abu vulkanik supaya material bangunannya tidak mengalami kerusakan.

\section{KESIMPULAN}

Berdasarkan analisa peta lokasi dan keletakan sumber daya arkeologi yang ada di Kabupaten Karo, situs-situs yang menjadi sumber daya arkeologi tersebut masuk dalam tingkat kerawanan tingkat sedang atau relatif membahayakan. Dampak dari abu vulkanik yang dihasilkan oleh letusan gunung api Sinabung masih berpotensi memberikan kerusakan jangka panjang pada situs-situs yang ada di sekitar gunung api Sinabung.

Untuk mengantisipasi kemungkinan dampak dari letusan gunung api Sinabung, dibutuhkan strategi penanganan, antara lain: memperkaya data sumber daya arkeologi yang mencakup data fisik cagar budaya dan data lingkungan yang disajikan dalam peta resiko bencana.

\section{DAFTAR PUSTAKA}

Auker, M.R., Sparks, R.S.J., Siebert, L. et al. (2013). A statistical analysis of the global historical volcanic fatalities record 2: 2. J Appl. Volcanol. https://doi.org/10.1186/2191-5040-22

BNPB. (2012). Peraturan Kepala Badan Nasional Penanggulangan Bencana No. 02 Tahun 2012 Tentang Pemodan Umum Pengkajian Risiko Bencana. Jakarta: BNPB.

Burley, DV. (1988). Tongan archaeology and the Tongan past. 2850-150 BP. Journal of World Prehistory.12, 337-92, 1998.

Capasso, Luigi. (2000). Herculaneum victims of the volcanic eruptions of Vesuvius in 79 AD. Lancet. 356. 13446. 10.1016/S0140-6736(00)02827-0.

Sieh, K., and D. Natawidjaja. (2000). Neotectonics of the sumatran fault, Indonesia, J. Geophys. Res.

Scovil, Gordon dan Anderson. (1977). "Guidelines for the Preparation of Statements of Environmental Impact on Archaeological Resources" dalam Schiffer, M.B dan G.J. Gumerman (ed) Conservation Archaeology. New York: Academic Press.

Troll, Valentin \& Deegan, Frances \& M. Jolis, Ester \& A Budd, David \& Dahren, Börje \& Schwarzkopf, L. (2015). Ancient Oral Tradition Describes Volcano-Earthquake Interaction at Merapi Volcano, Indonesia. Geografiska Annaler Series 
A Physical Geography. 97. 137-166. 10.1111/geoa.12099.

Wilson, T.M. Wilson, N.I. Deligne, J.W. Cole. (2014). Volcanic hazard impacts to critical infrastructure: A review, Journal of Volcanology and Geothermal Research, Volume 286, Pages 148-182, ISSN 0377-0273, https://doi.org/10.1016/j.jvolgeores. $\underline{2014.08 .030}$ 